\section{From formal to informal: executives who migrated to flexible work}

\author{
Han Na Kim \\ ESPM, Department of Business, São Paulo - Brazil \\ Maria José Tonelli \\ André Luis Silva \\ FGV-EAESP, Department of General Administration and \\ Human Resource (ADM), São Paulo - Brazil
}

Received on

02/20/2016

Approved on

09/06/2016

\section{Responsible editor:}

Prof. Dr. João Maurício Gama

Boaventura

Evaluation process:

Double Blind Review

\begin{abstract}
Purpose - Given the changes occurred in the organization and work, flexible employment contracts are generally associated with a search for more productive employees. The purpose of this research is to understand the behavioral changes needed by executives to face up to the reality of these new flexible models of work.
\end{abstract}

Design/methodology/approach - This paper presents the study that was undertaken in the city of São Paulo (SP - Brazil) with 30 executives who migrated from formal employment contracts/job positions to more flexible formats.

Findings - The results showed that the interviewees use various terms for describing themselves: consultant, independent, franchised, businessperson, councilor, among others, and suggested that they have to change their self-perceptions to be adapted to flexible work.

Originality/value - This study shows that the narratives that these executives use to illustrate their professional trajectories are related to how they deal with time, with their network and how they should change their mentality and behavior in order to achieve success. Lastly these professionals must display competence; even they are sometimes betrayed by their listless gestures, voice and look.

Keywords - flexible work; informal contract; constructionism; executives.

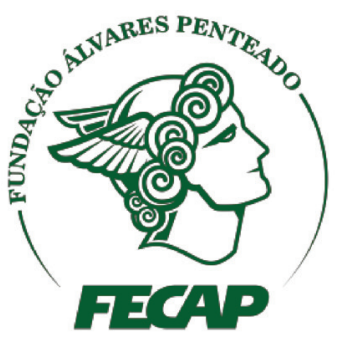

Review of Business Management

DOI: $10.7819 /$ rbgn.v0i0.2999 


\section{Introduction}

Since the late 1970 s, the flexible forms of employment contract have been concentred on investigations about the impact of flexible working arrangements both in organizational outcomes such as in the actual performance of workers (Baltes, Briggs, Huff, Wright, \& Neuman, 1999; Hill, Hawkins, Ferris, \& Weitzman, 2001; Kossek, Lautsch, \& Eaton, 2006; Pierce \& Dunham, 1992; Rubin, 1979; Russell, O’Connell, \& McGinnity, 2009; Stains \& Pleck, 1986, some examples). These studies ended up consolidating an ideology excessive in relation to the general understanding of this type of work (Anderson \& Kelliher, 2009; Barley \& Kunda, 2006), since the discussion focused on flexible contracts as a phenomenon only described in terms of the characteristics of labour market and companies (Galea, Houkes, \& Rijk, 2014; Green, Kler, \& Leeves, 2010; Greenberg \& Landry, 2011).

Considering that the previous research's focus argued the flexible work solely in terms of firms and markets, and this kind of focus constrains our ability to perceive, understand and shape the evolution of system of work and employment (Barley \& Kunda, 2006), this article aims to fill this theoretical gap. Using a constructionist approach were investigated 30 Brazilian executives who decided to migrate from formal employment contracts to more flexible formats. All these professionals had already held top management positions in Brazilian and multinational companies, but they decided to work in flexible activities. So, what behaviour changes were necessary for formal executives migrate to flexible work? To answer this question, we describe flexible forms of work in the next section; following the methodology design and then the results obtained in this research.

\section{Globalization and Changes in the Organization of Work}

Many contemporary authors try and explain the changes that occurred in the social, economic and political scenario that led to the current shape of global and local markets (Antunes, 2013; Azevedo, Tonelli, \& Silva, 2015; Bauman, 1999, 2001; Beck, 1999; Castells, 2007; Chahad, 2003; Giddens, 1991; Harvey, 1992; Heloani, 2003; Russell et al., 2009; Wood, 1992). But the conceptual lack of definition of globalization has made it difficult to have a broader and more consistent debate on this question. This difficulty largely arises from the fact that, as Bauman (1999) indicates, the very term 'globalization' was created to get around countless orthodox truths and, therefore, it ended up becoming an unquestionable expression.

The globalization is certainly the most widely used word of the last few years, because it is politically effective, however many different meanings it has (Beck, 1999). In other words, the term globalization has been used as an allencompassing discursive resource that accepts multiple considerations, depending on the intention and situation in which it is used. But the idea of globalization fosters the existence of three main myths: (i) the myth of incomprehensibility, which is an understanding that it is difficult to comprehend what is happening in today's world; (ii) the myth of service provision, which is the idea that growth in the service sector is going to save the work society; and (iii) the myth of costs, which fosters the need to drastically reduce salaries, as an alternative to solving the problem of unemployment (Beck, 1999).

The myth of service provision still lacks more convincing proof. The myth of incomprehensibility transmits much more recognition that life in society is complex, per se. It is, therefore, merely applied as a convenient way of giving a label to the difficulties that are inherent in the transformations being experienced on a global scale. Finally, there is a certain illusion surrounding the myth of costs, seeing that more and more people have a doctrinal conviction that "only radical labour and salary cost action can put an end to the spectre of unemployment" (Beck, 1999, p.115). 
The fact is that people coming from the most diverse regions, contexts and countries are experiencing very similar impacts in their lives because of the global transformations in society. It is in this sense that globalization makes the connection between local and global strengthening the social relations and the experiences of collective dramas. This interdependence is driven by advances in communication technology, information and transportation, as far as concerns elements such as advanced financial management computer systems, on-line operations management, flexible production, air transportation services, mobility infrastructure and the Internet (Castells, 2007; Giddens, 1991; Menezes, 2011).

It is no coincidence that this cycle of interdependence in the information age means that it is possible to find and create new jobs and ways of working, but the costs of these alternatives are susceptible to constant changes (Anderson \& Kelliher, 2009; Brandi, 2012; Findlay, Kalleberg, \& Warhurst, 2013). For example, many companies in advanced capitalist countries move part of their operations to countries where labour charges are less costly. According to Batt (2005), changes in the organization of work, mainly because of technological advances and the division of labour, are proof of the concern of the area of organizational studies to debate the changes that have occurred in the contemporary employment system based on the post-Fordist production model.

Moreover, contemporary work activities can be exported, while individuals manage to establish cooperation regimes in transnational and transcontinental schools, or even supply their labour through services measured by direct contact with consumer-customers (Beck, 1999). Organizations that work transnationally can organize their work and production processes by distributing it to regions in which production costs and labour charges are less costly (Chahad, 2003). This strategic alternative provides an organizational flexibility that maximizes the response of agents and economic units (Castells,
2007). Flexibility in the organization of work makes it obvious that globalization has intensified the bargaining power of businesspeople, since the owners of capital are finding more and more room for defining the rules of the labour market and the business logic in favour of growing financial returns (Bauman, 1999; Beck, 1999).

This scenario has contributed to trade unions and individuals look at flexibility of work organization as a form of precariousness (Azevedo et al., 2015; Barley \& Kunda, 2006; Brandi, 2012; Calvacante \& Prédes, 2010; Dedecca, 2006; Faria \& Rachid, 2006; Kremer \& Faria, 2005; Menezes, 2011; Piccinini, Oliveira, \& Rübeich, 2006), which result in situation like: salary cuts, the abolition of laws that protect worker salaries and problems involving labour negotiations with less well-qualified professionals (Anderson \& Kelliher, 2009; Chahad, 2003; Menezes, 2011).

In fact, before long, the flexible forms of work gained momentum and showed applicable to the situation. There was the reduction in stable and fulltime employment in favour of a series of ways of working, whose common denominator was flexibilization in terms of contracts, time, space and organizational charters. Flexible forms of working gained in strength at the time because they proved to be applicable and appropriate. As a result, because flexible working is embedded in the movement for restructuring production processes and the labour market, its spread has hastened the breakdown, dispersion and fragmentation of the organization of contemporary labour (Azevedo et al., 2015; Findlay et al., 2013; Green et al., 2010; Kovacs, 2004; Menezes, 2011; Piccinini et al., 2006).

Given these circumstances, individuals had to find alternative means of exercising their office in life and thus manage to preserve a place in the globalized labour market. As a result, many traditional workers launched themselves into flexible working activities, by which they managed to perform, as Beck (1999) indicates, the social role of a professional who is independent of organizational precepts. In order to be able to 
detail the characteristics of flexible work there now follow arguments on the subject.

\section{Flexible Work}

To present the inherent characteristics of flexible work, first its link with traditional work needs to be recognized. Globally, no specific limitations have been established on the characteristics of work in traditional or flexible regimes. However, a formal employment contract between a company and its employees in Brazil is governed by the rules of the Consolidation of the Labour Laws (CLT) In this case, formal contracts commonly comprise elements such as: fixed remuneration; a workplace supplied by the employer; there is no predetermined relationship period; the employee works fulltime in compliance of the contract; and the employee dedicates to working for a single employer. As showed by international researchers, this is the model that organized formal work in other countries (see, for instance, Cappelli, 1995; Gallagher \& Parks, 2001; Green et al., 2010; Greenberg \& Landry, 2011; Kalleberg, 2000).

Taking into consideration what formal employment contracts are, a flexible contract is considered to be any type of working relationship that does not comply with the criteria of a traditional labour relationship (Gallagher \& Parks, 2001; Greenberg \& Landry, 2011). The notion of flexibility requires a redistribution of power between the organization and worker, which implies an intention on the part of individuals to appropriate the resistance capacity of organizations, whose rigidity is ready to be overcome, when they become involved with professionals who have flexible employment contracts (Azevedo et al., 2015; Bauman, 1999; Faria \& Rachid, 2006; Galea et al., 2014; Giannikis \& Mihail, 2011; Green et al., 2010; Stavrou \& Kilaniotis, 2010).

The studies on flexible work intensified after the abrupt changes in work organization were generated by productive restructuring (see, for instance, Azevedo et al., 2015; Barber,
Dunham, \& Formisano, 1992; Baltes et al., 1999; Brandi, 2012; Grzywacz \& Marks, 2000; Hill et al., 2001; Kossek et al., 2006; Kremer \& Faria, 2005; Menezes, 2011; Piccinini et al., 2006; Pierce \& Dunham, 1992; Rubin, 1979; Saltzstein, Ting, \& Saltzstein, 2001; Stains \& Pleck, 1986). Such studies initially sought to discuss the impact of flexible working regimes both on organizational results as well as on worker performance. Generally speaking, the conclusion reached was that the impact of flexible working generally has a positive influence on both organizational results and worker performance.

For one side, studies indicate that the flexible working regimes have little influence on the workers' performances (Azevedo et al., 2015; Dunham, Pierce, \& Castaneda, 1987; Hicks \& Klimoski, 1981; Hill, Miller, Weiner, \& Colihan, 1998; Menezes, 2011). This happens because the organizations are the biggest beneficiaries when using flexible working contracts, since this strategy allows them to focus only on the hiring of services avoiding, therefore, the contact with all charges and bureaucracies is involved in formal labour relations. On the other hand, other studies assimilate flexible working as a positive alternative for the individuals (Brandi, 2012; Eaton, 2003; Faria \& Rachid, 2006; Frone, Russell, \& Cooper, 1992; Lewison, 2006). In this case, flexible hours emerge as a labour benefit, since the possibility to balance work activities and personal life contributes to better productivity capacity as a whole (Galea et al., 2014).

If the balance between personal and professional life is one of the questions that positively affects the performance of individuals in flexible working regimes, it is now better understood that flexible workers know that, in order not to remain at the mercy of the impositions of formal employment contracts, they need to constantly act in such a way as to create and justify their work within the context in which they find themselves. Therefore, these professionals consider three factors to justify their work: the usefulness of what they do; the social 
relevance of what they do; and the value generated by their work (Beck, 1999). This presupposes that working in a flexible regime means working for oneself and for others all the time (Bauman, 1999; Beck, 1999).

Workers who engage in the flexible work quickly realize that they have to deal directly with the resolution of problems that may arise in their professional practice. This circumstance strengthens one of the main characteristics of this professional: developing their own solutions - not to delegate them to others - or learning to adopt the widespread practices from their clients. It is in this sense that flexible working can be understood as a new form of professional practice that combines traditional and new ways of working in their realization. This is a practice that can be called itinerant professionalism (Barley \& Kunda, 2006).

Itinerant professionalism assumes that the flexible professionals are responsible to ensure their own employment benefits. To maintain them, the individuals need to constantly preserve their reputation in the market. It is important, because the professional reputation justifies, in the flexible work regime, the relevance of the services offered by the professional (Barley $\&$ Kunda, 2006). To reproduce and maintain a reputation in the market is not an easy task for flexible professionals, mainly because this type of work could be developed in different ways.

\section{I Contemporary studies on flexible working}

Recent investigative developments into flexible employment contracts have been the object of research in many regions and countries (Azevedo et al., 2015; Brandi, 2012; Brummelhuis, Haar, \& Lippe, 2010; Giannikis \& Mihail, 2011; Idiagbon-Oke \& Oke, 2011; Kremer \& Faria, 2005; Menezes, 2011; Russell et al., 2009; Stavrou \& Kilaniotis, 2010, few examples). Above all, recent studies on the theme are characterized by their approach to different aspects and focuses of the research.
Hayman (2009), for example, deals with the question of how the usability of flexible working time is perceived as an effective policy of non-traditional contractual regimes, considering it allows workers to balance their professional and private activities. A specific aspect of this study was that it used Australian offices as the research focus, because according to the author, most of the studies on flexible working are centred on North American cases. As a result, it is pointed out that a direct relationship exists between the perceived usability of flexible working hours and consolidation of a greater equilibrium in the time set aside for personal life activities. The same thing does not occur with individuals who work the traditional fixed number of hours.

Atkinson and Hall (2009) investigated the relationship between the implementation of flexible working regimes in the British National Health Service and the question of gender involved in this work environment. The authors start from an understanding that the question of gender is little investigated in the sphere of flexible working. It is argued that gender, specifically with regards to women, is still seen with a certain degree of neutrality in the sphere of these work regimes. The study concluded that it is necessary to provide evidence of the discussion of the issue of gender to ensure that flexible working policies are effectively applied for a wide variety of different workers. This focus will enable a series of barriers to be identified, which currently inhibit the capacity of flexible working regimes to offer the equally diversified range of benefits that arise from this form of work to women. The absence of such benefits contributes to the development of pronounced differences in the levels of selfconfidence of the workers, however much they are carrying out the same functions.

Green et al. (2010) were concerned with dealing with the issue of the precariousness generated by flexible contracts, based on the increased number of people earning low salaries and the poor quality of the jobs, which are characteristic of this type of work regime. The 
authors evaluated a set of elements of flexible employment contracts using a work quality index. This analysis revealed that flexible jobs are of a lower quality than those in traditional working relationships, although it is recognized that there are important objective and subjective differences with regards to the perception of what precisely quality is within the work sphere. It is concluded that, although in an objective sense the gains in flexible working regimes are insufficient to compensate for the loss of benefits coming from formal work, workers are relatively more satisfied with the value of their work than those who have formal working relationships. It is also noted that informal work offers fewer opportunities for the development of professional skills and for a return to the formal market, which are elements that contribute to strengthening the poor quality of these work positions.

Another perspective on the theme of flexible working can be seen in the study by Muse (2011), in which he investigates from the organizational perspective the reasons that led a major multinational company, in this case Merck and Company Inc., to adopt and develop global programs and initiatives for work flexibility. As a result, the organization being studied views flexibility as a positive element for business purposes, as it is for the workers themselves, because it provides the conditions for: flexible working arrangements to be a worker's right; results delivered within the established deadlines count much more than the amount of time spent every day arriving at them; flexibility helps the company be a better place to work; and the use of flexible forms of working does not limit worker career opportunities or promotion. Finally, it is pointed out that these results characterize the organization studied and for this reason they may differ in other organizations and cultures.

As we can observe, the contemporary debate on flexible working has emerged from efforts to research the different questions and aspects to be considered when dealing with this subject. However, a certain trend is perceived in the approaches that focus the discussion on: balancing time between personal life and work; the issue of the precarious nature of the work; gender relations and informal contracts; and the organizational focus on the use of flexible working.

However relevant these studies are to the debate and reflection on the subject, they also provide evidence of the absence of any empirical research, the focus of which is on investigating the behavioural changes that are necessary on the part of formal workers who move to flexible models of involvement with contemporary work, as is the case with this research. Considering that it is coherent to incorporate new empirical fields and the study focus for the debate on the subject, we set out below the methodological scope that gives the approach taken in this research into the subject.

\subsection{Flexible ways of working}

The flexible way of working is commonly associated with temporary work activities, outsourcing, consultancy work and selfemployment (Azevedo et al., 2015; Brandi, 2012; Gallagher \& Parks, 2001; Green et al., 2010; Menezes, 2011). However, many terms are used for designating flexible workers. To cite some examples: contingent worker, independent work provider, atypical worker, self-employed, informal worker, temp, and outsourced worker.

Kovacs (2004) believes that the term atypical worker is unsuitable, because it raises doubts as emerging forms of employment, particularly those deriving from the selection and recruitment processes currently being employed, become increasingly unconventional. The fact that the word 'flexible' is also associated with an understanding of 'new forms of work' it is unsuitable, since many of the forms of employment currently in use are not new. In fact, they represent much more a return to old forms of work, because they are carried out in either a part-time, temporary or independent way (Findlay et al., 2013). 
Given the difficulties associated with defining what a flexible worker is, it is appropriate to discuss distinctions between the terms used for designating them. A temporary worker has a triangular relationship, involving his employer, the company hiring the service and the individual who does the service. The independent worker or self-employed person is an individual who has the resources necessary for doing his work. In other words he is a worker who is, at the same time, a type of businessman. The part-time worker, on the other hand, adjusts to doing his work in shifts, whose duration and/or time for carrying them out, are variable, although they do not reach the number of working hours involved in full-time working scales (Anderson \& Kelliher, 2009; Brummelhuis et al., 2010; Greenberg \& Landry, 2011; Houseman, 2001; Kovacs, 2004; Kremer \& Faria, 2005; Piccinini et al., 2006).

In the search for definitions of the various forms of flexible work that exist, the encyclopaedia of the International Labour Organization (ILO) presented the legal framework differences in the terms associated with flexible working. The ILO took into consideration the different laws in force in the different countries, which have an influence on the conceptual definitions of the term, and conceptions of the workers in question. Table 01 shows the terms used by the ILO.

\section{Table 1}

\section{Definition of labour in ILO terms}

\begin{tabular}{|c|c|}
\hline Term & Definition \\
\hline Consultant & Adviser for institutions and people. \\
\hline Cooperatives & A business that belongs to and is controlled by its members, of which all workers can become associates. \\
\hline Employee & $\begin{array}{l}\text { A worker who has an explicit or implicit employment contract, which gives him/her a basic remuneration that } \\
\text { is not directly dependent on the income of the unit in which they work. }\end{array}$ \\
\hline $\begin{array}{l}\text { Atypical employment } \\
\text { or precarious } \\
\text { employment }\end{array}$ & $\begin{array}{l}\text { Employment relationship where employment security, considered one of the main elements in the employment } \\
\text { contract, does not exist. This term includes temporary work, work for a predetermined period, home working } \\
\text { and sub-contracted labour. }\end{array}$ \\
\hline $\begin{array}{l}\text { Temporary } \\
\text { employment }\end{array}$ & Employment contract that lasts for a limited time or is non-specific, without any guarantee of continuing. \\
\hline Telework & Distance work (including home working), using telecommunications and computer equipment. \\
\hline $\begin{array}{l}\text { Outsourcing; } \\
\text { Contracting out; } \\
\text { Subcontracting }\end{array}$ & The practice of buying goods or services from external suppliers, instead of producing them internally. \\
\hline $\begin{array}{l}\text { Contingent worker } \\
\text { or Casual worker }\end{array}$ & $\begin{array}{l}\text { A worker who works occasionally and intermittently. Such workers are employed for a specific number of hours, } \\
\text { days or weeks; they do not have the same terms and conditions as formal workers. (e.g. they are not entitled to } \\
\text { sick leave or paid vacations.) }\end{array}$ \\
\hline Seasonal worker & $\begin{array}{l}\text { A worker who is employed for fixed and limited periods, which are related to fluctuations in demand for labour } \\
\text { at different periods during the year. }\end{array}$ \\
\hline Part time worker & An employed person, whose normal working hours are less than those of a fulltime worker. \\
\hline Work at home & $\begin{array}{l}\text { Work carried out at home by a person, or in another place of their choice, which is different from the employer's } \\
\text { workplace; they are remunerated by the employer and the results, in products or service, is specified by the } \\
\text { employer, without any consideration of who provides the equipment, material or inputs used. }\end{array}$ \\
\hline Contract work & Work supplied by a contractor. \\
\hline $\begin{array}{l}\text { Informal } \\
\text { Employment }\end{array}$ & $\begin{array}{l}\text { Includes all types of remunerated employment (e.g. self-employment and employment) which is not registered, } \\
\text { regulated or protected by existing legal and regulatory bodies, as well as unpaid work that is carried out in a } \\
\text { not-for-profit enterprise. An informal worker does not have an employment contract, benefits, social protection } \\
\text { or trade union representation. }\end{array}$ \\
\hline Temporary work & Employment contract that lasts for a limited or unspecified time, without any guarantees of it continuing. \\
\hline
\end{tabular}

Fonte. Adapted from the International Labour Organization Thesaurus (2015). 
Because of the differences between the meanings given to a single term - flexible working - for this study 'flexible working' is taken to be: any form of work, for specific services purposes, performed by a professional for a contractor/ company. The amount received by him/her is negotiated directly between both, because it is a business relationship of eventual character and, therefore, without a formal work regime. Having presented the definition of flexible working adopted in this research, we set out below the methodological design of this research.

\section{Methodological Design}

This is a qualitative research (Bluhm, Harman, Lee, \& Mitchell, 2011), guided by the paradigm of social constructionism (Spink, 2004). This orientation helped us consider the reality researched as being endowed with meaning, constructed, local and specific, and based on the social interaction processes between individuals. Therefore, the analysis and interpretation of this study's data returned to the discursive practices and meanings constructed by those interviewed with regards to their experiences in the transition to more flexible ways of working.

Thirty Brazilian executives were interviewed. Numerically, males were 25 people (83\% of the total) and women were $5(17 \%$ of the total). With regards to age, 33\% of those interviewed are less than 39 years old; $12 \%$ are between 40 and 49; 7\% are between 50 and 59; and $1 \%$ of those interviewed is over 60 . With regards to their marital status, $77 \%$ are married. As for their level of education, $96 \%$ have completed a higher education course. With regards to dependents, $70 \%$ of those interviewed have children. As for their experience and area of activity as informal workers, $66 \%$ have more than ten years' experience; $23 \%$ work in the technology area; $16 \%$ are in management; $13 \%$ are in marketing; $13 \%$ are in insurance; $10 \%$ are in logistics; $6 \%$ are in research and development; $6 \%$ are in finance; $3 \%$ are in human resources; $3 \%$ are in public relations; and $3 \%$ are in franchising. The legal forms adopted are basically two: self-employed (20\%) and legal entity (80\%). The Table 02 shows the general characteristics of all interviews.

Data was collected by means of semistructured interviews, which were recorded for subsequent transcription. So that the questions asked of those participating in the research were answered in the most spontaneous way possible, they were guaranteed anonymity. All ethical precautions were taken, however, so that during the course of the work, information was not disclosed that might identify the participants who voluntarily contributed to this research.

All interviews took place with professionals who are active in São Paulo (SP/Brazil), the biggest Brazilian city with concentration of companies and highly qualified professionals in the country. Numerically, São Paulo is home to $38 \%$ of the 100 biggest private Brazilian companies; $63 \%$ of the international groups operating in Brazil; 17 of the 20 biggest banks; and 8 of the 10 biggest stock brokers (Fecomercio, 2012). Moreover, in 2009 (the last information available) the municipality of São Paulo had the biggest share in the Brazilian Gross Domestic Product (GDP), the value of which was R \$389 billion (Instituto Brasileiro de Geografia e Estatística [IBGE], 2011). The choice of the city of São Paulo, therefore, for carrying out the data collection was suitable for the purposes of this study. The Table 03 shows the labour characteristics of all interviews. 
Table 2

\section{General characteristics of interviews}

\begin{tabular}{|c|c|c|c|c|c|}
\hline Interview & Gender & Age & Academic background & Marital status & $\begin{array}{c}\text { Number of } \\
\text { children }\end{array}$ \\
\hline 1 & Male & 51 & Social communication & Married & 1 \\
\hline 2 & Male & 34 & Engineering & Married & 2 \\
\hline 3 & Male & 41 & Engineering & Married & 4 \\
\hline 4 & Female & 38 & Economy & Divorced & 0 \\
\hline 5 & Male & 31 & Business administration & Single & 0 \\
\hline 6 & Male & 49 & Geology & Married & 2 \\
\hline 7 & Male & 56 & Business administration & Married & 1 \\
\hline 8 & Male & 37 & Engineering & Married & 1 \\
\hline 9 & Male & 33 & Incomplete college degree & Married & 0 \\
\hline 10 & Male & 41 & Engineering & Married & 0 \\
\hline 11 & Male & 33 & Engineering & Married & 2 \\
\hline 12 & Male & 31 & Engineering & Married & 0 \\
\hline 13 & Male & 43 & Engineering & Married & 3 \\
\hline 14 & Male & 55 & International commerce & Married & 1 \\
\hline 15 & Male & 45 & Accounting & Married & 1 \\
\hline 16 & Male & 51 & Economy & Divorced & 4 \\
\hline 17 & Male & 36 & Business administration & Married & 1 \\
\hline 18 & Female & 33 & Business administration & Single & 0 \\
\hline 19 & Male & 35 & Engineering & Divorced & 0 \\
\hline 20 & Male & 55 & Law & Married & 1 \\
\hline 21 & Male & 47 & Business administration & Married & 3 \\
\hline 22 & Male & 48 & Business administration & Married & 2 \\
\hline 23 & Male & 40 & Accounting & Married & 2 \\
\hline 24 & Male & 43 & Information systems & Divorced & 0 \\
\hline 25 & Male & 54 & Marketing & Married & 2 \\
\hline 26 & Male & 57 & Information systems & Married & 2 \\
\hline 27 & Male & 61 & Law & Married & 1 \\
\hline 28 & Male & 44 & Economy & Married & 2 \\
\hline 29 & Female & 42 & Business administration & Married & 0 \\
\hline 30 & Female & 47 & Statistics & Divorced & 1 \\
\hline
\end{tabular}

With regards to the process of accessibility to the field and location of the participants of this research, different paths were used. First, São Paulo companies listed among the 100 biggest Brazilian companies in the annual ranking (in this case 2015) of the "Biggest and Best Companies to Work For" in Brazil by Exame magazine, were contacted. It was believed that these companies would have a vast range of active professionals working as third parties in service provision. But the companies contacted showed no interest in revealing how they related with the companies and/or outsourced professionals. After this unsuccessful attempt, we had recourse to direct contact with independent consultants who kept information about the services provided, via personalized websites. Unfortunately, the return was very low. This being so, we chose to use researchers' network of personal and professional contacts. Each professional interviewed was asked to indicate other professionals they knew who had the profile required by the research. In other 
words, the group of 30 participants in the research was formed using the snowball effect technique (Appolinário, 2006).

To help with the organization of the collected material, QSR NVivo 7 software was used. After organizing the material, it was possible to codify the data with the help of content analysis (Appolinário, 2006). It means that all data collected by interviews, were organized through thematic categories selected from the theoretical framework about flexible work, as well as the own recurring data that emerged from the respondents. This requires understanding that the data analysis was did on the following three questions-categories: (i) how did the flexibility work?; (ii) how you work in this flexible regime?; (iii) how is the market in which it operates?; (iv) how do you deal with customers?; (v) what professional problems do you face?; and (vi) intends to continue as a flexible worker? During the interpretation process placed on the content of the messages it was implicit and explicit in the words of the responses collected with the interviews. The results obtained are presented in the next section.

Table 3

\section{Labour characteristics of interviews}

\begin{tabular}{|c|c|c|c|c|}
\hline Interview & $\begin{array}{l}\text { Full period as CLT worker (in } \\
\text { years) }\end{array}$ & Area & $\begin{array}{l}\text { Labour definition } \\
\text { adopted }\end{array}$ & $\begin{array}{c}\text { Currently income level } \\
\text { compared to CLT (own } \\
\text { experience) }\end{array}$ \\
\hline 1 & 10 & Marketing & $\mathrm{PJ}$ & Higher \\
\hline 2 & 11 & Technology & Consultant & Below \\
\hline 3 & 12 & Insurance & PJ & Higher \\
\hline 4 & 14 & Insurance & PJ & Higher \\
\hline 5 & 8 & Franchise & PJ & Higher \\
\hline 6 & 10 & Insurance & PJ & Higher \\
\hline 7 & 12 & Business & PJ & Higher \\
\hline 8 & 21 & Insurance & PJ & Equivalent \\
\hline 9 & 8,5 & Business & Consultant & Higher \\
\hline 10 & 9,5 & Technology & PJ & Higher \\
\hline 11 & 5 & Business & PJ & Equivalent \\
\hline 12 & 7,5 & Technology & Consultant & Higher \\
\hline 13 & 17 & Marketing & PJ & Below \\
\hline 14 & 5 & Business & PJ & Below \\
\hline 15 & 8 & Tax planning & PJ & Higher \\
\hline 16 & 22,5 & Finances & PJ & Below \\
\hline 17 & 10 & Marketing & PJ & Higher \\
\hline 18 & 3 & Marketing & PJ & Higher \\
\hline 19 & 13 & Technology & Consultant & Higher \\
\hline 20 & 25 & $\mathrm{P} \& \mathrm{D}$ & PJ & Higher \\
\hline 21 & 9 & HR & Consultant & Higher \\
\hline 22 & 24 & Logistics & PJ & Higher \\
\hline 23 & 6 & Business & PJ & Below \\
\hline 24 & 11 & Technology & PJ & Higher \\
\hline 25 & 24 & Logistics & PJ & Higher \\
\hline 26 & 20 & $\mathrm{P} \& \mathrm{D}$ & PJ & Higher \\
\hline 27 & 30 & Public relations & PJ & Equivalent \\
\hline 28 & 11 & Logistics & PJ & Higher \\
\hline 29 & 10 & Technology & PJ & Below \\
\hline 30 & 20 & Technology & $\mathrm{PJ}$ & Below \\
\hline
\end{tabular}




\section{Research Results}

When respondents were asked about how they perceive themselves as flexible professionals, considering their work trajectories in this type of activity, they used various terms to describe themselves, such as: consultant, businessman, independent, franchised, outsourcer and councillor. These different definitions are aligned with the argument defended by Kovacs (2004) regarding the difficulties associated to clarify the term. It's also aligned with Gallagher and Parks (2001) when they state that multiple names can be aggregated to the activities developed by flexible workers. But, most of the interviewees used the term 'consultant'. Sometimes those interviewed consider this to be a trivial, popular and very broad term to describe the type of activity exercised by 'qualified and special' professionals, as they consider themselves to be because they have knowledge and experience that they acquired throughout their long professional experience. Below is an example:

Interviewee 7: [...] I don't like the word consultant. I myself use councillor... I've thought a lot about this, because I don't like the word consultant. Moreover, consultants supply consultancy services: do this, do that. I think that's right in some cases. But not in my segment. Companies don't want someone to give them recommendations; they want people to do things. I can say that the right term is outsourced. But outsourced has become associated with the cleaning area and security companies [...] things need to be better defined.

All professionals believe that they are different from most consultants, because they consider themselves being holders of knowledge and practicing experience needed in the market. Actually, this behaviour shows that all of them possess a very high level of self-confidence. But still that the executives in flexible work believe that they are the best some of them are betrayed by their gestures, posture, voice intonation and dejected look when they say this discourse. This feature points to Barley and Kunda (2006) when they describe the existence of need for flexible professionals to preserve their reputation to be able to justify their work. Nevertheless, it was observed that throughout the data collection process some interviewees were sometimes betrayed by their gestures, voice and apathetic gaze, regardless of how much they used the phrase 'I am good'.

Interviewee 2: You have to have confidence in yourself. In the company or with our work colleagues we have to trust in ourselves in order to receive new projects.

In addition to self-confidence in their professional skills and their belief in professional success, again and again interviewees talked about their work as a 'mission'. In other words, it is like work that, when it is being done, promotes good in itself and for all the others who benefit from the results. In addition to understanding work as a mission, the interviewees resort to use of the word 'happy' and 'proud' to show the value they attribute to the work they do. Sometimes, this value idea was transmitted when professionals value the ability to solve problems and make decisions to help their customers like as Barley and Kunda (2006) statement that one of the striking features of flexible professionals is to develop their own working solutions. Moreover, respondents' satisfaction with flexible ways of working highlights the aspect pointed out by Green et al. (2010) regarding the fact that flexible workers experience greater levels of satisfaction with the work they do than their colleagues who work under formal employment contracts.

Interviewee 3: Now, I really feel I have a different mission. When someone comes here saying: 'I want to increase my business but I don't know how to', it gives 
me pleasure to help them grow through my work. I think it's great, because you receive recognition and people come up to you later and say: 'Thank you for helping me'. That's when I feel I'm making a difference for them too.

Another category, which proved relevant to an understanding of the behaviour of flexible workers, has to do with their professional experience and the construction of their current career. Most of the interviewees talked about their professional experiences with pride and selfesteem, because, they have made a lot of effort to reach their current success. This feature reinforces the Barley and Kunda (2006) idea about the fact that professional flexible, by does not delegate its functions to third parties, has the responsibility for ensuring their own achieved benefits.

When the interviewees were asked 'How did you get into flexible working?' we observed that these professionals used a variety of reasons as their justification for the transition to flexible working. Generally speaking, we noted that because of the fact that all had had previous experience as formal employees, most of them have some level of dissatisfaction with the formal work regime. The words of the interviewees reveal that the formal regime work tends to be associated with a bureaucratic and rigid system in which: the financial benefits are not so attractive; the work environment generally causes stress; and the employer offers limited growth prospects.

Some professionals over 40 emphasized the issue of getting old as one of the reasons for the transition to flexible working. According to their accounts, the Brazilian market did not like older professionals, generally those over 40 . This often occurs because younger workers, in addition to coming into the market with a lot of information and technological knowledge, are prepared to do the same work for lower salaries. The technological advance is one of the major aspects responsible for changes that have occurred in the organization of contemporary work.
Interviewee 14: I have a lot of friends who are now between $40-45$ years old and they're scared, because they're about to be thrown out of the labour market.

Some interviewees revealed that the time needed for establishing themselves financially after the transition to flexible working had no impact on their decision to migrate and/or remain in flexible work. This is a very subjective issue, however, and it varies from interviewee to interviewee, because it is related to the level of personal satisfaction, whether that refers to achieving stability immediately after the transition to flexible working, or achieving certain desired standard of living, per se, that is something coming from the private sphere. This issue shows that there is no common measure that defines the moment of stability in flexible working and this largely agrees with the argument put forward by Green et al. (2010) with regard to the subjective aspects inherent in understanding what quality is within the formal or informal work sphere.

Interviewee 7: It took me five years to reach a stable situation. [...] In the beginning you're never certain if a new project is going to come in when you deliver what you've been doing. [...] You end up going through some difficult moments, and that's why having a monthly income ends up becoming a struggle.

Generally speaking, the family has an influence on the choices of the interviewees with regards to the transition to flexible work. On the part of the families it was noted that there was a lot of expectations, anxiety and even a certain prejudice with regards to flexible working, all issues that are only finally laid to rest when the interviewees manage to present tangible results from their new work activities. It is in this sense that, in fact, the workers face the constant need to justify the relevance of their work within their context and to the people around them, since as Beck (1999) and Bauman (1999) point out, the 
flexible professional needs, in fact, to work for others and for himself at the same time.

When the interviewees were asked about 'What it is like to work under a flexible regime?', it was noticeable that following the transition the interviewees perceived and/or reaffirmed that informal work demands that the professional confronts a series of decisions, such as: whether to work as a legal entity, given that customer companies may demand invoices for services provided; whether to obtain a fixed work space/ address; and how to allocate the use of time to carrying out activities. In most of the accounts it is noted that it is by way of informal work that interviewees seek to align work time, their network of professional contacts and personal life. Furthermore, they perceive that this change requires them to modify their mentality and behaviour in regards to how they are going to leave old habits acquired as managers of major corporations behind, in order to acquire the new skills, they need for informal working.

Another aspect that was obvious in the reports of the interviewees is that knowledge is one of the basic elements for doing their work. The interviewees behave proactively when it comes to acquiring knowledge. For example, many of them are enrolled in MBA courses, or even PhDs. These professionals also study the needs of their customers; they buy and read many books; they are heavy users of the Internet and new software packages; they register with entities in their areas of operation in order to map out contacts with other professionals; and they take advantage of the time not spent with clients to invest part of their income in acquiring knowledge.

Interviewee 21: In my area, no one is convinced by mere persuasion. We consultants need to be very well-grounded. After all, the information is available to anyone. And it's my duty to know how to process this information and how to qualify and quantify it.

Time is constantly fragmented in flexible working, whether the interviewees are dedicating themselves to customers, to acquiring knowledge, to the family or even to resting. However, they appreciate their capacity to control the use of their time, a control that is greater that it was under the formal regime. In addition to flexible hours being characteristic of informal work, as indicated by Houseman (2001) and Kovacs (2004), recognition by the interviewees of the flexibility of time as a positive aspect of their work, reaffirms the arguments of Frone et al. (1992), Eaton (2003), and Lewison (2006), with regards to this characteristic being one of the attractions for professionals who work under informal employment regimes.

As executives have already held managerial positions for long periods, a series of adaptations needed to do when they migrate to flexible working arrangements appear. The adaptation is not an easy process, since it raises many doubts about what behaviours to adopt in order to show a good performance in the services made by flexible mode. In this sense, Barley and Kunda (2006) are assertive in stating that flexible working is a professional activity that requires the junction between new and traditional modes of working to its full realization. But considering the statements of the research participants, apparently, these changes are not easy, because they are situations that have an impact on the psychological aspect of these professionals.

Interviewee 21: After you change it's a constant learning process. First it was horrible, because you leave the comfort zone you were used to and this is a conflict. To reorganize your thoughts you need to deal with things cautiously. [...] And in my current work I know how to deal with people; it's something that demands a lot of tact and a lot of caution.

Finally, it was noted that some interviewees still indicated a certain type of 'recipe' for the success of flexible workers. According to them, it is necessary to follow this recipe on a daily basis, because financial success will be the consequence of this behaviour. 
Interviewee 8: You have to cultivate appropriate habits to obtain good results and this is going to reflect directly in your pocket.

Interviewee 21: It's a gift of the person... If someone's not good, they're not going to pick up work.

Interviewee 22: First of all you need to have an excellent relationship with the market and having this type of relationship is better than having money in the bank. When you have a 20-year relationship with a strong market, naturally one customer is going to pass you on to another.

Considering the aspects debated so far and the results obtained from the process of interpreting the reports of the interviewees, we finally come to the conclusions of this research.

\section{Conclusions}

This research was developed by the investigation of 30 Brazilian executives who decided to migrate from formal employment contracts to more flexible formats. To achieve this knowledge about flexible work was systematized. A constructionist was used to analyse the interviews and, below, are highlighted the main conclusions of this research.

\section{I General conclusions}

It's remarkable that formal professionals who migrate to flexible work use various terms to describe themselves, whether consultant, businessman, independent, franchised, outsourcer, or adviser. However, the most of the interviewees used the term 'consultant', regardless of how much some of them consider this term to be trivial, popular and very all-encompassing for describing the type of activity exercised by the 'qualified and special' professionals consider themselves to be because of the knowledge and experience they acquired throughout their consistent and long- lasting professional working lives.

Although the interviewees had already been working flexibly for some time, most of them talked proudly and with self-esteem about their previous professional experiences in formal regimes. It was perceptible that this characteristic was used as a resource capable of reaffirming the hard work these professionals had put into achieving success in their work activities currently engaged.

But as for the justifications given for the transition to flexible work, the reasons proved to vary. Generally speaking most of the interviewees had some degree of dissatisfaction with the formal work regime. In these cases, the formal work regime tends to be associated with a bureaucratic and rigid system, which makes the financial benefits less attractive in this market; the organizational working environment becomes stressful; and the employer ends up offering them limited growth prospects. These particular aspects contribute to the interviewees become independent professionals, regardless of the fact that those who were dismissed by their last employer would have found no difficulty in getting a new position in the formal market had they wished to.

It was observed that the family reaction and the way in which the interviewees deal with their personal lives are factors that make it feasible for them to continue working informally or prevent them from doing so. The responsibilities inherent in sustaining the home financially or even the time dedicated to family life bear a direct relationship to the behaviour of the interviewees with regard to their flexible work. In some cases, it was possible to identify that the transition to informal work had not been taken kindly by the family.

\subsection{Contributions}

So, the first contribution of this research is that results reinforce the notion that is prevalent in Brazil that a 'real job' is associated with formal work regimes with their rules and CLT work- 
related benefits. But since the families of some interviewees perceived no difference following the decision of the latter to migrate to informal work, in these cases there was either little financial impact on the family's consumption style, or the family members were firm in offering their support to the interviewee, given his/her reasons for undertaking this transition. Whether supported or not, the families of the interviewees exercise a strong influence on their choices relating to the transition to flexible work. Family members create a lot of expectation, anxiety and even a certain prejudice in relation to informal work and these are issues that can only be mitigated when the interviewees are successful in presenting tangible results from their new work activities. It is in this sense that formal workers who decide to migrate to informal activities face the constant necessity to justify the relevance of their work within the context and to the people around them.

Another aspect that was evident in the reports of the interviewees is that knowledge is one of the basic elements for doing their work. This includes both technical and practical knowledge and the capacity to suggest innovative solutions to their clients. Knowledge is considered to be important because the interviewees indicate that being well-informed is essential for directly negotiating with the owners or top managers of their company clients. This is why they consider there is no space for error during this contact; having good information and a solid knowledge base, whether it is used for implementing or negotiating customer projects, is elementary.

The interviewees' satisfaction with flexible working can be perceived from the fact that they reveal that even though they currently work longer hours than before, they still prefer the informal regime compared to the one when they worked under formal employment contracts. In flexible work, their time is constantly fragmented, whether dedicated to clients, to acquiring knowledge, to family or even to rest. But is precisely because this fragmentation exists that they manage to control the way in which they use their own time, and this control was not possible when they worked under the formal regime.

Another aspect that became evident from the reports of the interviewees is that to do their work they need to create solid professional contact networks. It is via these networks that they manage to acquire new knowledge and references from clients and projects. Moreover, considering their experiences with informal work, the interviewees indicated a certain type of 'reservation' in regards to their success in flexible working. According to them, among other things they need to be disciplined, to establish a good and strong relationship with the market and to deal with their clients directly. Following this recipe on a daily basis provides them with the conditions necessary for financial success to be a consequence of this behaviour.

It was also noticeable that the interviewees have a high level of self-confidence with regards to their professional activities. It is no coincidence that the interviewees always said that they are good at what they do and so they tried to reinforce this idea by means of their postures, the intonation of their voice and their facial expressions. What is unusual is that throughout the whole data collection process it was apparent that at times some of these professionals were betrayed by their gestures, voice and apathetic gaze, however much they said they were good at what they do. What in fact appears is that, regardless of their gestures, they really believe in their competence to work flexibly, above all because they consider the type of work they do as a 'mission' and, therefore, they are happy and proud to be able to show the value of what they do.

Considering all behaviour changes that emerged in the transition process of formal workers to flexible working regimes, we can conclude our second contribution which is about the fact that a transition process to flexible work demands that the individuals thus involved undergo a change in both mentality and behaviour. It is necessary for them to give up the old habits they acquired as managers of major corporations to 
acquire new skills that are pertinent to informal work. They need to recognize that they have to leave the situation of being a manager who gives orders behind, to become someone who only has themselves to depend on when carrying out their activities. Certainly, these behavioural changes are not easy, above all because they have a direct impact on the psychological aspect of these professionals, since they need to find new ways of thinking about and sensing what they do.

This research also evidences the multiple elements involved in the transition process of formal workers to more flexible ways of working. This was revealed as a complex process, whose definition and assimilation of its consequences may assume various forms and have a variety of impacts. This study indicates that the research approach to this type of phenomenon does not allow researchers to adopt methodological choices and a simplistic understanding. It is in this sense that the transition to informal ways of working creates a challenge in terms of developing alternative ways of apprehending the different dimensions of its nature not only for the professionals who engage in such work, but also for the researchers who are interested in the phenomenon and for the organizations employ it.

Finally, this research draws attention to an important phenomenon that may be of interest to other researchers in the area of Human Resources Management. The contemporary debate about flexible work has followed a certain trend in focusing discussion on balancing time between personal life and work, the question of the precarious nature of work, gender relations and informal contracts, and the focus of organizations on the use of flexible work.

\subsection{Agenda for future studies}

The results of this research indicate that it's important to explore some other phenomena that are connected to executives in flexible work: the impact exercised by the family in the decision regarding the transition, the role of the search for information/knowledge, the use of flexible time, the development of solid contact networks, and finally the central role played by the self-confidence that is characteristic of the professionals who work flexibly. Second, could be important to develop more detailed studies on the phenomenon that occurs with professionals from other hierarchical levels, in addition to those who are active in middle and top management levels. This will favour the identification of possible peculiarities in the transition process to flexible working, in detriment to the professional origins of the individuals.

Although the reasons that led executives to adopt a flexible work model emerge from different reasons, this research leads us to understand that this kind of decision is not easy, because it could be a result of than mere choice of each person, but a necessity. As this insight emerged as an inference from this research approach - and not necessarily from our empirical data - its aspect points out a possible limitation of our study. But we hope that the future studies can debate this research focus to improve the knowledge on flexible work and executives working in Brazil.

\section{References}

Anderson, D., \& Kelliher, C. (2009). Flexible working and engagement: The importance of choice. Strategic HR Review, 8(2), 13-18. doi:10.1108/14754390910937530

Antunes, R. (2013). Riqueza e miséria do trabalho no Brasil 2. São Paulo: Boitempo.

Appolinário, S. (2006). Science methodology: Philosophy and research practice. São Paulo: Pioneira Thomson Learning.

Atkinson, C., \& Hall, L. (2009). The role of gender in varying forms of flexible working. Gender, Work and Organization, 16(6), 650-666.

Azevedo, M. C., Tonelli, M. J., \& Silva, A. L. (2015). Contratos flexíveis de trabalho: Diferentes perfis de trabalhadores qualificados brasileiros. Revista de Administração, 50(3), 277-291. doi: $10.5700 /$ rausp 1200 
Baltes, B., Briggs, T. E., Huff, J. W., Wright, J. A., \& Neuman, G. A. (1999). Flexible and compressed workweek schedules: A meta-analysis of their effects on work-related criteria. Journal of Applied Psychology, 84(4), 496-513.

Barber, A. E., Dunham, R., \& Formisano, R. A. (1992). The impact of flexible benefits on employee satisfaction: A field study. Personnel Psychology, 45(1), 55-76. doi:10.1111/j.1744-6570.1992. tb00844.x

Barley, S. R., \& Kunda, G. (2006). Contracting: A new form of professional practice. Academy of Management Perspectives, 20(1), 45-66. doi:10.5465/AMP.2006.19873409

Batt, R. (2005). Introduction. In S. Ackroyd, R. Batt, P. Thompson, \& P. S. Tolbert (Eds.). The Oxford handbook of work and organization (pp. 19-30). Oxford: Oxford University.

Bauer, M. W., \& Gaskell, G. (2000). Pesquisa qualitativa com texto, imagem e som: um manual prático. Petrópolis: Vozes.

Bauman, Z. (1999). Globalization and its human consequences. London: Polity Press.

Bauman, Z. (2001). Modernidade líquida. Rio de Janeiro: Jorge Zahar.

Beck, U. (1999). What is it globalization? São Paulo: Paz e Terra.

Bluhm, D. J., Harman, W., Lee, T. W., \& Mitchell, T. R. (2011). Qualitative research in management: A decade of progress. Journal of Management Studies, 48(8), 1866-1891. doi:10.1111/j.14676486.2010.00972.x

Brandi, A. C. D. (2012). Flexibilização da jornada de trabalho e sua evolução: Aspectos relevantes. Revista Cientifica Eletrônica do Curso de Direito, 1(2), 1-13.

Brummelhuis, L. L. T., Haar, J. M., \& Lippe, T. V. D. (2010). Collegiality under presure: The effects of family demands and flexible work arrangements in the Netherlands. The International Journal of Human Resource Management, 21(15), 28312847. doi:10.1080/09585192.2010.528666

Cappelli, P. (1995). Rethinking employment. British Journal of Industrial Relations, 33(4), 563602. doi:10.1111/j.1467-8543.1995.tb00456.x

Castells, M. (2007). A sociedade em rede (10a ed.). São Paulo: Paz e Terra.

Cavalcante, G. M. M., \& Prédes, R. (2010). A precarização do trabalho e das políticas sociais na sociedade capitalista: Fundamentos da precarização do trabalho de assistente social. Libertas, $10(1), 1-24$.

Chahad, J. P. Z. (2003). Mercado de trabalho, segurança de emprego e de renda no Brasil: Estágio atual $e$ as liçôes de experiência profissional: Estudo e análise com vistas à definiçâo de políticas, programas e projetos relativos ao mercado de trabalho brasileiro. São Paulo: FIPE-Ministério do Trabalho e Emprego.

Dedecca, C. S. (2006). Flexibilidade e regulação de um mercado de trabalho precário: A experiência brasileira. Anais do Colóquio Internacional de Novas Formas do Trabalho e Desemprego: Brasil, Japão e França numa Perspectiva Comparada, São Paulo, SP, Brasil, 1.

Dunham, R. B., Pierce, J. L., \& Castaneda, M. B. (1987). Alternative work schedules: Two field quasi-experiments. Personal Psychology, 40(2), 215-242. doi:10.1111/j.1744-6570.1987. tb00602.x

Eaton, S. C. (2003). If you can use them: Flexible policies, organisational commitment, and perceived performance. Industrial Relations, 42(2), 145-166. doi:10.1111/1468-232X.00285

Faria, G. S. S., \& Rachid, A. (2006). Gestão de pessoas em tempos de flexibilização do trabalho. Revista de Ciências Gerenciais, 10(12), 86-95.

Fecomercio. (2012). Cidade de Sáo Paulo seria a 40 a economia do mundo. Retrieved from http:// 
www.fecomercio.com.br/?option=com_institucio nal\&view=interna\&Itemid $=12 \&$ id $=4895$

Findlay, P., Kalleberg, A. L., \& Warhurst, C. (2013). The challenge of job quality. Human Relations, 66(4), 441-451. doi:10.1177/0018726713481070

Frone, M. R., Russell, M., \& Cooper, M. L. (1992). Antecedents and outcomes of workfamily conflict: Testing a model of the workfamily interface. Journal of Applied Psychology, 77(1), 65-78.

Galea, C., Houkes, I., \& Rijk, A. D. (2014). An insider's point of view: how a system of flexible working hours helps employees to strike a proper balance between work and personal life. The International Journal of Human Resources Management, 25(8), 1090-1111. doi:10.1080/0 9585192.2013 .816862

Gallagher, D. G., \& Parks, J. M. (2001). I pledge thee my troth contingently, commitment and the contingent work relationship. Human Resource Management Review, 11(3), 181-208. doi:http:// dx.doi.org/10.1016/S1053-4822(00)00048-6

Giannikis, S. K., \& Mihail, D. M. (2011). Flexible work arrangements in Greece: A study of employee perceptions. The International Journal of Human Resource Management, 22(2), 417-432. doi:10.1080/09585192.2011.540163

Giddens, A. (1991). As consequências da modernidade. São Paulo: UNESP.

Green, C., Kler, P., \& Leeves, G. (2010). Flexible contract workers in inferior jobs: Reappraising the evidence. British Journal of Industrial Relations, 48(3), 605-629. doi:10.1111/j.14678543.2009.00742.x

Greenberg, D., \& Landry, E. M. (2011). Negotiating a flexible work arrangement: How women navigate the influence of power and organizational context. Journal of Organizational Behavior, 32(8), 1163-1188. doi:10.1002/job.750

Grzywacz, J. G., \& Marks, N. F. (2000). Reconceptualizing the work family interface: An ecological perspective on the correlates of positive and negative spillover between work and family. Journal of Occupational Health Psychology, 5(1), 111-126.

Harvey, D. (1992). The condition of postmodernity. Cambridge: Blackwell Publishers.

Hayman, J. R. (2009). Flexible work arrangements: Exploring the linkages between perceived usability of flexible work schedules and work/life balance. Community, Work \& Family, 12(3), 327-338.

Heloani, J. R. (2003). Gestão e organização no capitalismo globalizado: História da manipulaçâo psicológica no mundo do trabalho. São Paulo: Atlas.

Hicks, W. D., \& Klimoski, R. J. (1981). The impact of flexitime on employee attitudes. Academy of Management Journal, 24(2), 333341. Retrieved from http://www.jstor.org/ stable/255845

Hill, J. E., Miller, B. C., Weiner, S. P., \& Colihan, J. (1998). Influences of the virtual office on aspects of work and work/life balance. Personnel Psychology, 51(3), 667-683. doi:10.1111/j.1744-6570.1998. tb00256.x

Hill, J. E., Hawkins, A. J., Ferris, M., \& Weitzman, M. (2001). Finding an extra day a week: The positive influence of perceived job flexibility on work and family life balance. Family Relations: Interdisciplinary Journal of Applied Family Studies, 5O(1), 49-58. doi:10.1111/j.17413729.2001.00049.x

Houseman, S. N. (2001). Why employers use flexible staffing arrangements: Evidence from an establishment survey. Industrial \& Labor Relations Review, 55(1), 149-170. doi:http://www.jstor.org/ stable/2696191

ILO. (2015). International Labor Organization Thesaurus: goals, functions and political impacts. Recuperado de: http://library.fes.de/pdf-files/ iez/10279.pdf

Instituto Brasileiro de Geografia e Estatística. (2011). Produto interno bruto dos municípios 2005-2009. 
Retrieved from http://www.ibge.gov.br/home/ estatistica/economia/pibmunicipios/2005_2009/ pibmunic2005_2009.pdf

Idiagbon-Oke, M., \& Oke, A. (2011). Implementing innovative flexible work practices in Nigerian local firms: Implications for management of change in less-developed countries. Journal of Occupational and Organizational Psychology, 84(3), 518-543.

Kalleberg, A. L. (2000). Nonstandard employment relations: Part-time, temporary and contract work. Annual Review of Sociology, 26, 341-365. doi:10.1146/annurev.soc.26.1.341

Kossek, E. E., Lautsch, B. A., \& Eaton, S. C. (2006). Telecommuting, control, and boundary management: Correlates of policy use and practice, job control, and work family effectiveness. Journal of Vocational Behaviour, 68(2), 347-367. doi:http://dx.doi.org/10.1016/j.jvb.2005.07.002

Kovacs, I. (2004). Flexible employment in Portugal. Sociologias, 6(12), 32-68. doi:http://dx.doi. org/10.1590/S1517-45222004000200003

Kremer, A., \& Faria, J. H. (2005). Reestruturação produtiva e precarização do trabalho: $\mathrm{O}$ mundo do trabalho em transformação. Revista de Administração da Universidade de São Paulo, 4O(3), 266-279.

Lewison, J. (2006). The work/life balance sheet so far. Journal of Accountancy, 202(2), 45-50.

Menezes, P. C. S. (2011). Mercado de trabalho e flexibilização no Brasil e na Itália. Anais do Congresso Brasileiro de Sociologia, Curitiba, PR, Brasil, 15.

Muse, L. A. (2011). Flexibility implementation to a global workforce: A case study of Merck and Company. Community, Work \& Family, 14(2), 249-256.

Piccinini, V. C., Oliveira, S. R., \& Rübeich, N. V. (2006). Formal, flexível ou informal? Reflexôes sobre o trabalho no Brasil. In V. C. Piccinni, L. Holzmann, I. Kovacs, \& V. N. Guimarães (Orgs.). O mosaico do trabalho na sociedade contemporânea (pp. 93-118). Porto Alegre: Ed. UFRG, 2006.

Pierce, J. L., \& Dunham, R. B. (1992). The 12-hour work day: A 48-hour, eight-day week. Academy of Management Journal, 35(5), 10861999. doi:http://www.jstor.org/stable/256542

Rubin, R. S. (1979). Flexitime: Its implementation in the public sector. Public Administrative Review, 39(3), 277-279. doi:http://www.jstor.org/ stable/975953

Russell, H., O’Connell, P. J., \& McGinnity, F. (2009). The impact of flexible working arrangements on work-life conflict and work pressure in Ireland. Gender, Work and Organization, 16(1), 73-97. doi:10.1111/j.14680432.2008.00431.x

Saltzstein, A. L., Ting, Y., \& Saltzstein, G. (2001). Work family balance and job satisfaction: The impact of family-friendly policies on attitudes of government employees. Public Administrative Review, 61(4), 452-467. doi:10.1111/00333352.00049

Spink, M. J. P. (Org.) (2004). Práticas discursivas e produção de sentidos no cotidiano: Abordagens teóricas e metodológicas. São Paulo: Cortez.

Stains, G. L., \& Pleck, J. H. (1986). Work schedule flexibility and family life. Journal of Occupational Behaviour, 7(2), 147-153. doi:10.1002/job.4030070207

Stavrou, E., \& Kilaniotis, C. (2010). Flexible work and turnover: An empirical investigation across cultures. British Journal of Management, 21(2), 541554. doi:10.1111/j.1467-8551.2009.00659.x

Wood, T., Jr. (1992). Fordismo, toyotismo e volvismo: Os caminhos da indústria em busca do tempo perdido. Revista de Administração de Empresas, 32(4), 6-18. 


\section{Authors:}

1. Han Na Kim, PhD in Business Administration, FGV-EAESP, São Paulo Business School, Brazil.

E-mail: hannakim@espm.br

2. Maria José Tonelli, PhD in Social Psychology, PUC-SP, School of Psychology, Brazil.

E-mail: maria.jose.tonelli@fgv.br

3. André Luis Silva, PhD in Business Administration, FGV-EAESP, São Paulo Business School, Brazil.

E-mail: andre.luis.silva@fgv.br

\section{Contribution of each author:}

\begin{tabular}{|c|c|c|c|}
\hline Contribution & Han Na Kim & Maria José Tonelli & André Luis Silva \\
\hline 1. Definition of research problem & $\sqrt{ }$ & $\sqrt{ }$ & \\
\hline 2. Development of hypotheses or research questions ( empirical studies ) & $\sqrt{ }$ & $\sqrt{ }$ & \\
\hline $\begin{array}{l}\text { 3. Development of theoretical propositions } \\
\text { ( theoretical Work ) }\end{array}$ & $\sqrt{ }$ & & \\
\hline 4. Theoretical foundation/ Literature review & $\sqrt{ }$ & $\sqrt{ }$ & $\sqrt{ }$ \\
\hline 5. Definition of methodological procedures & $\sqrt{ }$ & $\sqrt{ }$ & \\
\hline 6. Data collection & $\sqrt{ }$ & & \\
\hline 7. Statistical analysis & $\sqrt{ }$ & & \\
\hline 8. Analysis and interpretation of data & $\sqrt{ }$ & & \\
\hline 9. Critical revision of the manuscript & $\sqrt{ }$ & $\sqrt{ }$ & $\sqrt{ }$ \\
\hline 10. Manuscript Writing & $\sqrt{ }$ & $\sqrt{ }$ & $\sqrt{ }$ \\
\hline
\end{tabular}

